\title{
TEORI EKONOMI DAVID RICARDO, THOMAS ROBERT MALTHUS DAN JEAN BAPTISTE SAY
}

Oleh:

\author{
Nurul Wahida Aprilya (90100118110) \\ Fakultas Ekonomi dan Bisnis Islam UIN Alauddin Makassar \\ e-mail:wahidaprilya@gmail.com
}

\section{A. Teori David Ricardo (1772-1823)}

David Ricardo merupakan anak ketiga dari 23 bersaudara dari keluarga yahudi yang bernama Abraham Israel Ricardo, yang lahir di London pada tahun 1772. David ricardo tertarik dengan ilmu ekonomi dimulai sejak tahun 1799 ketika ia tinggal di Bath saat memulai membaca The Wealth of Nation Adam Smith. Pada tahun 1817 dia mempublikasikan karya bukunya yang berjudul "On the Principle of Political Economy and Taxation" (Faruq \& Mulyanto, 2017:78).

Jika Adam Smith diakui sebagai pakar utama dan pelopor pemikiran ekonomi Mazhab Klasik, maka Ricardo menjadi pemikir yang paling menonjol di antara segenap pakar Mazhab Klasik tersebut.

Teori ekonomi yang dikembangkan oleh David Ricardo menyangkut empat pokok permasalahan yaitu: Teori tentang nilai dan harga barang dan berkaitan dengan itu, Teori tentang distribusi pendapatan sebagai pembagian hasil dari seluruh produksi dan disajikan sebagai teori upah, Teori sewa tanah, Teori bunga dan laba, Teori tentang perdagangan internasional, dan Teori tentang akumulasi dan perkembangan ekonomi (Suprapto, 2021:137). Adapun Teori Kuantitas dari David Ricardo yang menyatakan bahwa kuat atau lemahnya nilai uang sangatlah tergantung pada jumlah uang yang beredar. Apabila jumlah uang berubah menjadi dua kali lipat, maka nilai uang akan menurun menjadi setengah dari semula, dan begitu pula sebaliknya (Saidy, 2018:33).

Berikut pemikiran David Ricardo, antara lain:

1. Pemikiran moneter 
David Ricardo berpendapat untuk menjaga stabilitas moneter suatu negara, maka sistem moneternya itu harus menggunakan Standar nilai tukar emas, yang artinya uang yang beredar di suatu negara baik dalam bentuk simpanan ataupun kredit dapat dikonversikan dengan harga emas tetap sama nilainya dengan uang kertas. Dalam bukunya, David Ricardo mengatakan bahwa "Pihak yang mengeluarkan uang kertas harus mengatur pengeluarannya itu berdasarkan harga emas, bukan berdasarkan kuantitas uang kertas yang beredar" (Skousen, 2009:123).

2. Hukum Pendapatan yang Menurun

Pemikiran lain Ricardo adalah The Law of Deminishing Return (LDR) yang artinya Hukum Pendapatan yang Semakin Berkurang. Disini ada beberapa asumsi-asumsi yang terdapat dalam LDR, yaitu: 1. Tanah adalah faktor produksi utama (contonya seperti pertanian), 2. Upah tetap riil yang konstan pada level subsisten berdasarkan "hukum upah besi”, 3. Kapital atau modal tetap (merupakan satu peralatan yang diperuntukkan untuk satu tenaga-tenaga kerja menghasilkan jumlah satuan produk yang tetap).

3. Keunggulan Komparatif

David Ricardo merupakan sosok yang sangat mendukung perdagangan bebas, dimana kontrobusinya terlihat ketika ia mengembangkan teori "Hukum Keuntungn Komparatif" yang dituliskan pada buku on the Principle of Political Economy and Taxation, yang dimana Hukum tersebut menyatakan bahwa "perdaganagn bebas akan menguntungkan kedua belah pihak, dan yang saling mengejutkan adalah perdagangan bebas akan membuat suatu negara melakukan spesialisasi meskipun suatu negara memiliki keuntungan absolut dalam produk tertentu.

4. Teori Upah Besi (Iron Wage Theory)

Teori upah besi merupakan upah riil dalam jangka panjang yang cenderung berpengaruh terhadap upah minimum yang diperlukan untuk menyokong 
kehidupan pekerja. Upah tidak dapat jatuh dibawah tingkat subsistensi karena tanpa subsisten, buruh tidak akan mampu bekerja.

\section{Teori Nilai Kerja}

Ricardo menjelaskan bahwa nilai tukar suatu barang ditentukan oleh ongkos yang perlu dikeluarkan untuk menghasilkan suatu barang. Biaya itu berupa biaya yang dikeluarkan untuk bahan mentah dan upah buruh yang besarnya hanya cukup untuk dapat bertahan hidup atau yang disebut upah alami (natural wage). Kalau harga yang ditetapkan lebih besar daripada biaya-biaya, maka dalam jangka pendek perusahaan akan menikmati laba ekonomi. Kelebihan penawaran barang akan mendorong harga-harga turun pada keseimbangan semula dikarenakan biaya-biaya bahan mentah relatif konstan. Oleh sebab itu Ricardo menyimpulkan bahwa yang paling menentukan tingkat harga adalah tingkat upah alami.

6. Teori Sewa Tanah

Ricardo menjelaskan bahwa "Jenis tanah berbeda-beda: ada yang subur, kurang subur, hingga yang tidak subur sama sekali. Produktivitas tanah yang subur lebih tinggi dan dengan demikian untuk menghasilkan satuan unit produksi diperlukan biaya (biaya rata-rata dan biaya marginal) yang lebih rendah pula. Semakin rendah tingkat kesuburan tanah jelas semakin tinggi pula biaya rata-rata dan marginal untuk mengelolah tanah tersebut, dan juga jika semakin tinggi biayanya maka keuntungan per hektar tanah menjadi kecil pula. begitupula sebaliknya”. Jadi teori David Ricardo sangat memperhitungkan tinggi rendahnya sewa tanah berdasarkan tingkat kesuburan tanah dan belum memperhitungkan letak tanah yang ternyata juga mampu mempengaruhi tinggi rendahnya sewa tanah (Faruq \& Mulyanto, 2017:87).

\section{B. Teori Thomas Robert Malthus (1766-1834)}

Thomas Robert Malthus lahir pada tanggal 13 februari tahun 1766 di Surrey, Inggris. Pada tahun 1805 Malthus diangkat menjadi profesor sejarah modern dan ekonomi 
politik di perguruan tinggi East India Company College di Haileyburry. Pada tahun 1978 dia pertamakali mempublikasikan karya bukunya yang berjudul "Essay on Population" yang dicetak hingga pada cetakan ke-enam (Faruq \& Mulyanto, 2017:88).

Salah satu pemikiran Thomas Robert Malthus yang terkenal adalah tentang Kependudukan. Dalam bukunya Eassay on Population, Malthus menyatakan bahwa angka peningkatan populasi manusia tidak dibarengi dengan tersedianya jumlah makanan di dunia, sehingga ledakan penduduk baginya adalah ancaman. Malthus juga menekankan pentingnya untuk melaukan pembatasan laju perkembangan populasi penduduk (Novianto, 2017). Jalan keluar yang ditawarkan oleh Malthus adalah menunda usia perkawinan dan mengurangi jumlah anak (Todara \& Smith, 2006). Pertumbuhan penduduk mengakibatkan pertambahan kebutuhan manusia akan barang dan jasa.

Menurut Malthus, penduduk bertambah menurut deret ukur $(2,4,8,16,32 \ldots$ dan seterusnya), sedangkan makanan bertambah menurut deret hitung $(1,2,3,4,5 \ldots$ dan seterusnya). Akibatnya jumlah barang dan jasa, termasuk maknan, tidak seimbang dengan jumlah penduduk. Teori yang dikemukakan oleh Malthus tersebut merupakan sebuah prediksi pesimistik terkait dengan kelangkaan pangan dimasa yang akan datang (Muna \& Qomar, 2020:2).

Robert Malthus mengemukakan beberapa berpendapat tentang kependudukan, yaitu:

1. Penduduk apabila tidak ada pembatasan akan berkembang biak dengan cepat dan memenuhi dengan cepat beberapa bagian dari permukaan bumi.

2. Manusia untuk hidup memerlukan bahan makanan, sedangkan laju pertumbuhan makanan jauh lebih lambat (deret hitung) dibandingkan dengan laju pertumbuhan penduduk (deret ukur) (Conway, 2015).

\section{Teori Jean Baptiste Say (1767-1832)}


Jean Baptiste Say merupakan tokoh ekonomi penting Perancis yang lahir di Lyon, Prancis pada tahun 1767 tepat sembilan tahun sebelum The Wealth of Nation dicetak. Say sangat mengagumi Adam Smith, Say juga sangat berjasa dalam melakukan kodifikasi pemikiran Smith dan dirangkum dalam bukunya "Traite d'Economie Politique" pada tahun 1803, dan mendukung paham Laissez Faire (Atmanti, 2017:516).

Hukum Say yang terkenal adalah penawaran menciptakan permintaannya sendiri atau dikenal dengan Supply Creates its Own Demand. Hukum Say didasarkan pada assumsi bahwa nilai produksi selalu sama dengan pendapatan (Deliarnov. 2014). Ilustrasinya adalah bahwa semakin besar panen yang diperoleh petani maka semakin besar pula jumlah pembelian yang dilakukan oleh petani. Sebaliknya panen yang buruk akan mengurangi penjualn komoditas pada umumnya (Skousen, 2012).

Say mengatakan bahwa yang menciptakan permintaan bukanlah uang, tetapi produk barang atau jasa. Say juga berkata bahwa uang itu hanyalah alat tukar, dan penyebab riil dari depresi ekonomi bukanlah kekurangan uang, melainkan kurangnya penjualan oleh para petani, pengusaha, dan produsen barang dan jasa lainnya. Dalam bukunya Say mengatakan bahwa "yang memfasilitasi penjualan bukanlah melimpahnya uang, melainkan banyaknya produk lain... uang tak lebih dari alat tukar, ketika pertukaran selesai, maka yang terjadi ialah seoarang yang membayar suatu produk dengan produk” (Kates, 1998:23). Kunci untuk mendapatkan standar hidup yang lebih tinggi adalah dengan menaikkan pendapatan atau produktivitas. Dimana dengan menciptakan produk baru yang lebih baik maka akan membuka pasar baru dan menaikkan konsumsi, hal ini akan mendorong konsumsi yang tidak bermanfaat bagi perdagangan, karena kesulitannya terletak di dalam penyedian sarana, bukan menstimulasi keinginan untuk mengonsumsi. Hal ini sejalan dengan perkataan Say, dia mengatakan bahwa "pemerintah yang baik akan menstimulasi produksi, sedangkan pemerintah yang buruk akan menstimulasi konsumsi” (Skouen 2009). 


\section{DAFTAR PUSTAKA}

Atmanti, H. D. (2017). Kajian Teori Pemikiran Ekonomi Mazhab Klasik dan Relevansinya pada Perekonomian Indonesia. JEB17: Jurnal Ekonomi dan Bisnis, 2(02).

Conway, E. (2015). 50 Gagasan Ekonomi yang Perlu Anda Ketahui. Jakarta: Esensi Erlangga Group.

Deliarnov. (2014). Perkembangan Pemikiran Ekonomi. Edisi Ketiga. Jakarta: Rajawali Pers.

Faruq, U. A., \& Mulyanto, E. (2017). Sejarah Teori-Teori Ekonomi.

Kates, S. (1998). Say's Law an the Keynesian Revolution. Cheltenhem: Edward Elgar.

Muna, T. I., \& Qomar, M. N. (2020). Relevansi Teori Scarcity Robert Malthus Dalam Persepektif Ekonomi Syariah. SERAMBI: Jurnal Ekonomi Manajemen dan Bisnis Islam, 2(1), 1-14.

Saidy, E. N. (2018). Uang dalam Tinjauan Ekonomi Islam. Laa Maisyir: Jurnal Ekonomi Islam, 4(2).

Skousen, M. (2012). Sejarah Pemikiran Ekonomi. Sang Maestro Teori-teori Ekonomi Modern. Jakarta: Prenada.

Skousen, M. (2009). Teori-Teori Ekonomi Modern. Jakarta: Prenada.

Suprapto, M. S. (2021). Perkembangan Pemikiran Ekonomi dan Kontroversi.

Todaro, M. C., \& Smith, S. C. (2006). Perkembangan Ekonomi. Jilid 1. Edisi Kesembilan. Jakarta: PT. Gelora Aksara Pratama. 